Anitra Goriss-Hunter, Adele Echter, Taiwo Oseni, Sally Firmin

\title{
'UINDOING' GENDER: HOW THE SCHOOL OF SCIENCE, ENGINEERING AND INFORMATION TECHNOLOGY (SEIT) WOMEN'S GROUP WORKS ACROSS UNIVERSITY AND COMMUNITY LINES TO PROMOTE INCLUSIVE STEMM
}

\begin{abstract}
Research on gender and education in industrialised and developing countries suggests that schools and universities are sites of 'doing' rather than 'undoing' gender. Deutsch (2007) contends that 'doing gender' refers to social interactions that reproduce conventional and limiting notions of gender construction and that 'undoing gender' refers to social interactions that reduce gender difference and open up other possibilities. In this paper we consider how educational institutions can be strategic sites of influence in undoing gender and we investigate some ways that gender is 'undone' through the example of the work of the Science, Engineering and Information Technology Women's Group (SEITWG) located in the Faculty of Science and Technology at Federation University Australia. For this purpose, a self-study methodology understood as a professional reflection was used. The paper explores how the informal coalition of SEITWG works as 'wilful subjects', on the one hand, coming up against some of the 'brick walls' of dominant discourse that attempt to limit women's participation in STEMM (science, technology, engineering, mathematics, and medicine). On the other hand, SEITWG attempts to move beyond the restrictions of conventional gender narratives to encourage more women to participate in STEMM by foregrounding the presence of women already active in the area; mentoring women students and staff; supporting a range of their colleagues' endeavours to research and teach for inclusion; embedding gender analysis into the curriculum; and promoting workplace cultural change.
\end{abstract}

Keywords: gender, STEMM, education, university

Anitra Goriss-Hunter, PhD, Federation University Australia, a.goriss-hunter@federation.edu.au

Adele Echter, Ms, Federation University Australia, a.echter@federation.edu.au

Taiwo Oseni, PhD, Federation University Australia, t.oseni@federation.edu.au

Sally Firmin, Ms, Federation University Australia, s.firmin@federation.edu.au 


\title{
"ODPRAVLJANJE« SPOLA: ŽENSKA SKUPINA ŠOLE ZA ZNANOST, STROJNIŠTVO IN INFORMACIJSKE TEHNOLOGIJE TER PROMOCIJA INKLUZIVNEGA STEMMA NA UNIVERZI IN V SKUPNOSTI - POVZETEK
}

\begin{abstract}
Raziskave na področju spola in izobraževanja v industrializiranih razvitih državah kažejo, da so šole in univerze prizorišča »delovanja«, ne pa »odpravljanja« spola. Deutsch (2007) trdi, da se »delovanje spola nanaša na socialne interakcije, ki reproducirajo tradicionalne in omejujoče pojme o konstrukciji spola, »odpravljanje spola « pa se nanaša na socialne interakcije, ki zmanjšujejo spolno razliko in omogočajo nove poti. V tem članku razmišljamo, kako lahko izobraževalne institucije postanejo strateška prizorišča vplivanja na »odpravljanje« spola, in raziskujemo nekatere od načinov, kako je lahko spol »odpravljen «, prek primera dela Ženske skupine za znanost, strojništvo in informacijsko tehnologijo (the Science, Engineering and Information Technology Women's Group, SEITWG), ki deluje na Fakulteti za znanost in tehnologijo Avstralske zvezne univerze. Uporabljena je bila metodologija samoizobraževanja, razumljena kot strokovna refleksija. Članek raziskuje, kako (ne)formalna koalicija SEITWG na eni strani deluje kot »zavesten subjekt«, ki se sooča z »opečnimi zidovi« dominantnega diskurza, ki želi omejiti žensko sodelovanja na področjih STEMM (torej na področjih znanosti, tehnologije, strojništva, matematike in medicine). Hkrati želi SEITWG prekoračiti konvencionalne omejitve in spodbuditi več žensk, da bi sodelovale na zgoraj omenjenih področjih, in sicer tako, da v ospredje postavlja prisotnost žensk, ki so že aktivne na teh področjih, spodbuja mentorstvo študentk in žensk, zaposlenih na fakulteti, podpira prizadevanja svojih kolegic pri raziskovanju in poučevanju, ki je usmerjeno $k$ vključevanju, z učnimi načrti, ki vsebujejo analize spola, in s promocijo kulturnih sprememb na delovnem mestu.
\end{abstract}

Ključne besede: spol, STEMM, izobraževanje, univerza

\section{INTRODUCTION}

While ensuring equal access to education for all school and university students is an important structural change, research on gender and education in industrialised and developing countries suggests that schools and universities are sites of 'doing' rather than 'undoing' gender (Connell, 1989; Thorne, 1993; Pascoe, 2007; Unterhalter, 1999; Renold 2006; Thoman, White, Yamawaki and Koishi, 2008; Steffens, 2011; Steele, 1997). A number of studies follow the lead of West and Zimmerman (1987), Cheryan, Plaut, Davies and Steele (2009), and Spelke (2005) to argue that universities and schools are sites where academics, teachers, students and textbooks construct meanings of gender that disadvantage female students (Biraimah, 1982; Lloyd, Mensch and Clark, 2000; Cohen and Duberly, 2017 and Clancy, 2017). Despite some research work in this area, understandings of how education at university and school levels can challenge inequitable social norms and undo restrictive gender relations have advanced slowly. In particular, there is a general understanding of a number of concerns or factors that negatively impact female participation in STEMM subjects and careers, but these issues are generally not being successfully addressed. In this paper we discuss the ways in which a university women's group seeks to work along fault lines of gender and power across faculties in an Australian university to undo traditional gender limitations. The Science Engineering Information Technology Women's Group (SEITWG), located in the Faculty of Science and Technology at 
Federation University Australia, draws on academics from a number of faculties to move towards undoing stereotypical notions of gender and promoting inclusive participation in STEMM activities and studies. SEITWG moves beyond deficit views of the inevitability of notions of female exclusion from masculine networks of power within a STEMM environment in the academy. Instead, the group works to create spaces of belonging for those who are undoing dominant forms of gender.

\section{THE PROBLEM - WOMEN UNDERREPRESENTED IN AND AVOIDING STEMM}

"According to the Australian government, women occupy fewer than one in five senior researcher positions in Australian universities, and make up less than half of the overall STEMM workforce" (Sadler, 2017). Women are deterred from studying STEMM or pursuing a career in STEMM for a number of reasons, including stereotyping (Dasgupta and Stout, 2014), lack of family support, lack of access to jobs (Mavriplis et al., 2010), low numbers of girls studying STEMM programmes (Vogt, Hocevar and Hagedorn, 2007), perceptions of content being too difficult (Hill, Corbett and St Rose, 2010), and gender bias in software design (Tavani, 2016). The under-representation of women in STEMM education and workforce impacts on more than women. It is a missed opportunity. Women bring a unique perspective that shapes and influences the STEMM disciplines (Milgram, 2011). Women bring variety and different perspectives into the workplace, which leads to diversity of ideas (Cohen, 2014). Women respond to closer relationships and engagement with their teachers (Vogt et al., 2007). Technology can be leveraged to afford closer relationships with our women students, and provide positive experiences (Cohen, 2014). In addition, women are known to be leading adopters in technologies such as social media (Correa, Hinsley and Gil de Zuniga, 2010). Many studies argue that technology is a valuable tool in engaging student learning (Chen, Lambert and Guidry, 2010), and enhancing a student-centred approach (Hannafin and Land, 1997).

\section{WILFUL SUBJECTS UNDOING GENDER}

To investigate the complexities of the problems outlined in the previous section, this paper draws on the ideas of Deutsch and Ahmed. Deutsch contends that 'doing gender' refers to social interactions that reproduce gender difference and that 'undoing gender' refers to social interactions that reduce gender difference (2007, p.122). The university is one of a number of crucially important education institutions that influence how individuals learn gendered behaviour. Research on gender and education suggests that there are several pathways or authorities that can reproduce gender inequality in educational environments such as universities (Baker, 2010; Guarino, 2017; Nath, 2017). These issues include the organisational structure of universities and the management practices that constitute it, the formal curriculum (both how knowledge is organised and whether it has explicit gender content), peer group norms, and academics' beliefs, expectations and interactions with students. Strategies proposed to undo gender largely focus on women's 
access to non-traditional career areas; quotas for diverse representation; professional development around gender issues, reorganising and adding explicit gender content to the curriculum; and promoting open discussion and critical reflection about gender (Gilbert and Gilbert, 1998; Nath, 2017).

If the previously mentioned strategies were implemented, universities could be settings for undoing gender. Gender theorists identify educational settings, such as universities, as strategic sites of influence because education systems are the places where open debate about gender relations is likely to happen (Connell, 1989; Myton, 2018). Yet we know little about educational interventions that fulfil this potential role, as previous research and policies have focused on issues of access. While increased enrolment in education represents an important structural change, it does not ensure that everyday interactions will be altered. The ideas explored in this paper respond to Deutsch's call to spotlight the social processes that underlie resistance to conventional gender relations and focus on how to change the power dynamics and inequities that may exist in situations that privilege traditionally gendered politics (2007, p. 107).

In this paper we consider how education can be a strategic site of influence in undoing gender and we also investigate some ways that gender is 'undone' in planned and unplanned moments through the example of the work of the SEIT Women's Group (SEITWG). Members of this diverse group foreground the presence of women in STEMM and their attempts to encourage more women to enter non-traditional areas. Intent on doing the 'diversity work' (Ahmed, 2017) of increasing the participation of women and ethnically diverse people in the traditionally male domain of STEMM, SEITWG attempts to bring about dialogue between expressions of support for diversity and the actual experiences of those who embody diversity. In doing so, SEITWG aims to breach what Ahmed refers to as the academic 'brick walls' or barriers to undoing gender by foregrounding the presence of women already active in the area; mentoring women students and staff; supporting a range of their colleagues' endeavours to research and teach for inclusion; embedding gender analysis into the curriculum; and promoting workplace cultural change.

The authors, who are SEITWG members, reflect upon the ways in which they work individually and collectively to effect change. A common thread identified concerning the ways individuals approached diversity work was a wilful rejection of dominant narratives that attempted to constrain women within traditional spheres. While wilfulness is often defined in negative terms as an obstinate and sometimes perverse condition, in our narratives, wilfulness is a positive and enabling force that has supported our efforts to re-write normative narratives and author our own stories. Our identification as 'wilful subjects' is in line with Sara Ahmed's (2010, p. 5) notion of wilfulness:

To be called obstinate or perverse because you are not persuaded by the reason of others? Is this familiar to you? Have you heard this before? When you are charged with wilfulness it is as if your being is an insistence on being, a refusal to give way, to give up, to give up your way. Can what we are charged with 
become a charge in Alice Walker's sense, a way of being in charge? If we are charged with wilfulness, we can accept and mobilize this charge.

Thus, the actions and philosophy of the group of 'wilful subjects' (Ahmed, 2012) emphasizes the need for change among both individuals and social structures in order to transform the university.

\section{IN CONTEXT}

SEITWG was formed in response to the problems outlined in the previous section concerning the lack of women in higher levels of academia and in STEMM in general. This group was initiated as a means of bridging the gender gap in STEMM and draws on female academics and research students not only in the STEMM field but also in interdisciplinary fields of gender studies and education. Gender studies, by illustrating the potential of interdisciplinary scholarship in today's scientific and technical university can increase the representation of women in STEMM fields (Colatrella, 2014). Collaborations between STEMM, gender studies and education fields is being developed within SEITWG and this is helpful for preparing women to participate in SEIT, where the need of a diverse workforce with scientific and technical knowledge is clear and cannot be overemphasised.

SIETWG's founding members are located in the discipline area of Information Technology (IT) in the School of Science, Engineering and Information Technology (SEIT) at Federation University. SEIT is currently made up of approximately 72 staff members across four discipline areas: Science (geoscience), Engineering, Mathematics and Information Technology. The geoscience discipline area has eight staff members, three of which are women. Of the fourteen people employed in the discipline of Mathematics, four are women. With about twenty staff members, the engineering discipline is predominantly male dominated and had only one woman for over a 10 -year period. This has recently changed with a new woman engineer recently appointed. The IT discipline, though having a greater number of staff, is not very different, with only six women in a pool of thirty-one staff. All these women, with the exception of one, are employed on a full-time basis, and are expected both to teach and undertake research. Research within the school is mainly quantitative with an emphasis on Data Mining, Machine Learning, and Artificial Intelligence. The school however also has qualitative researchers in the areas of Health Informatics and Information Systems, amongst which are women. The SEIT women are of diverse ages ranging from early thirties to late fifties but all are 'junior' or entry level academics. They identify with a range of cultural and ethnic backgrounds. The group is predominantly middle class with two members self-identifying as coming originally from low socio-economic backgrounds. There is also a range of ethnic and racial identifications in the group membership encompassing the following: Caucasian Australian, Nigerian, and Asian backgrounds.

The difficulties that women experience in the SEIT environment are concerned with the following issues. The limited number of women in these fields raise difficulties in finding 
mentors and such diversity within the range of SEIT disciplines as well as the junior status of the group members means that it is sometimes hard to identify colleagues for collaborations. Women in SEIT are generally concentrated in teaching only and junior positions. This situation combined with the predominance of qualitative research conducted by women in SEIT makes it difficult to form research collaborations in an environment that privileges quantitative research. Hence, SEITWG was formed to encourage women to engage with research by sharing ideas and supporting each other. SEITWG brings together women from Federation University's schools of engineering and IT, and education.

SEITWG has become a haven for academic individuals with a variety of scientific, technological and linguistic skill sets and experiences to come together and bridge the fault lines where possible and understand the barriers if evident. There is a general recognition within the group that working in isolation does not work as effectively as working together to find commonalities and disparities in thinking and practices. The thinking connections allow for critical debate around notions of gender fault lines and ways of operating that can be found between, beside, and behind the lines.

Group members wilfully work along gendered fault lines. As women are still predominantly primary care givers (Jericho, 2017), SEITWG members juggle family responsibilities with work responsibilities. In addition, the nature of academic work does not seem to recognise the difference between work and private space at times. These gendered responsibilities and concerns surface in planned and unplanned conversations as SEITWG members juggle roles within the workplace and home. For instance, members of the group are comfortable bringing their children to meetings if necessary as there are times when members opt to come to meet while on leave or outside of usual business hours.

\section{METHODOLOGY}

In order to complete this project, the authors have adopted a reflective self-study methodology. This adoption of reflective and self-study methodologies ensures that researchers' perspectives and everyday practices can be examined, and socially constructed realities can be investigated (Crotty, 1998; Flick, 2007). From the initial impetus to reflect on our practice as academics, the choice of a self-study methodology (Hamilaton and Pinnegar, 2009) was logical as it was self-initiated, enabled the authors to extend their own reflective practices and also to develop 'powerful insights' into their teaching and learning practices within the academy (Russell, 2010).

In its discussion of and reflection on teaching and other academic issues of practice, the self-study methodology enables the interrogation of issues of practice with the aim of transformative change (LaBoskey, 2004). Being reflexive and focused on specificity, a self-study methodology "suggests that our understanding of teaching and learning derives from contextualised knowledge, by a particularly reflective knower" (Bass, Anderson-Patton and Allender, 2002, p. 56). The research design also draws on LaBoskey's (2004) notion of self-study - self-initiation, qualitative, interactive and focused on 
improvement. Self-initiation occurred as individually and collectively we were struggling with normative notions of gendered identities and how to move beyond these ideas in our work as academics and as members of the wider community outside the university. Also, some time needed to elapse before group members were comfortable discussing their own ideas and perceptions of situations. This echoes the work of Samaras and Freese (2009) who state that they "initially had a fear of sharing our work and making ourselves vulnerable - but as we moved to a feeling of openness and learning together, we found ourselves framing and reframing our understandings" (p. 12). For the authors, sharing and discussing reflective writing opened up this process of allowing group members to read, think about and comment on the ideas and experiences of other group members.

Our data sources included discussions in and after monthly meetings, meeting notes, email exchanges, reflective writing, journaling, observations and dialogue concerning course curriculum planning and implementation. We analysed these data sources, identifying the choices made, questioning why they were made, looking for challenges encountered and observing how these had been met. Discussions ensued about recurring patterns, common experiences and also changes that had been made. These conversations, reflections and analyses inform our reflections upon the ways in which SEITWG wilfully works towards the 'undoing' of gender. All four authors have drawn on their professional reflections of SEITWG meetings, activities and discussions in order to write this paper. The authors have also all adopted the role of a "sceptical colleague" (Pinnegar and Hamilton, 2009, p. 113) as they acted as sounding boards for the discussions concerning the reflections.

There are 10 members of SEITWG and all occupy 'junior' or base-level academic positions. It is a culturally and linguistically diverse group with approximately half the membership having a Caucasian background. From the 10 members of SEITWG, the four authors seized the opportunity presented by the formation of SEITWG to develop a community of practice and pursue research concerning how effective the group is in achieving its aims.

\section{REFLECTION ON SEITWG - A COMMUNITIES OF PRACTICE AND SOCIAL NETWORKS PERSPECTIVE}

SEITWG is being shaped as a community of practice $(\mathrm{CoP})$ within a regional university setting. This well-established concept regarding a group of people who work together on projects and/or interests, improving their abilities as they continue to interact and work towards common goals, draws on the idea of the powerfulness of collective learning and shared participation in group projects (Lave and Wenger, 1991). Wenger posited the idea that communities of practice constitute a web of social relationships that participate in the wider world (Lave and Wenger, 1991 cited in Cundill, Roux and Parker, 2015). The SEITWG CoP is a social network with intentions to effect change and promote ideas by collaboration in research and ongoing collegial conversations. Kezar and Gehrke (2017) 
argue that "social networks and CoPs are related to situated cognition theories of change that suggest changes, learning, and improvement occur within organizations as individuals on the ground engage with others" (p. 325). A university might be described as a larger community of practice within which many smaller CoPs reside.

The success of the current SEITWG CoP is partly due to the interdisciplinary nature of the participants, each individual bringing with them different sets of knowledge, work and learning practices. The inclusion of members from the School of Education with different experiences of social interactions with peers provides another layer to the group's understanding of the scholarly interaction/communication/research nexus. Wenger states that "the concept of identity serves as a pivot between the social and individual" (Wenger, 1999, p. 145) and that individuals derive their sense of identity within a CoP by what they bring to the group. An understanding of how the differing levels of research expertise add to the wider knowledge of the group has been observed in the writing of this article. SEITWG members involved in writing together are learning together and developing a sense of common purpose, not only discovering the richness of interdisciplinary research but also the supportive strength of collegiality and critical friendship which in turn contributes to innovative ways of working and problem solving. One of the great pleasures of working in SEITWG is the strength of commitment and wilful charge that pervades a great deal of the work completed.

Some of the practical ways that SEITWG undoes gender stereotypes is through engaging with potential members and students both within and outside the university. These initiatives include a mentoring scheme built on a three-way connection between female students from a local high school, university women students, and university Alumni. The difficulties involved in appropriately matching students with mentors meant that the scheme is not currently available and will need some work before it is mobilized again. Various social opportunities were used to assist women students and faculty to establish connections. These events included morning and afternoon teas for all faculty women staff and students; lunch with the Dean of SEIT and Head of School; and 'coffee catch ups' where academic and administrative staff come together for brief conversations about issues concerning them or solely for the social interaction. More formal opportunities were established in the form of meetings for all women staff and students to identify specific issues of concern to women on campus and online. Additionally, a project titled Robo girls (female school students exploring the field of robotics) was suggested but not developed.

\section{DISCUSSION}

From conversations and critical reflections, it appears that there are many ways that gender is 're-done' and also 'undone' in education institutions. A common thread running through the situations, interactions and thinking that enabled 'undoings' of gender by SEITWG members was the common identifications of a wilful pleasure concerning the act/s of undoing. The other aspects of these acts of undoing that was noted was that they 
were part of a process or action - they were in the process of becoming something else or changing, of moving beyond stereotypes during these acts of undoing. These elements interact in our examples of challenging gender stereotypes so that the 'undoing' of gender is revealed as an action or process enabled by the diversity work of wilful subjects that is a catalyst for shiftings beyond gender norms with a frisson of pleasure at moving away from normative narratives. These wilful undoings of gender occur chiefly in the area of education (curriculum design), policy implementation and institutional culture - the latter intertwine and overlap.

\section{Wilful Undoing of gender through education}

In this paper we consider how education can be a strategic site of influence in undoing gender and we also investigate some ways that gender is 'undone' in planned and unplanned moments through flexible teaching practices that 'seize the teachable moment'. The paper also investigates how these teachable moments of undoing gender might be further developed by embedding gender analysis into the curriculum, engaging students and tutors in critical reflection and dialogue, and emphasising the need for change among both individuals and social structures. Classroom discussions and the use of cultural and political vignettes (CPVs) are two pedagogical approaches used by SEITWG members to promote the examination and undoing of gender relations. These approaches were used by SEITWG members teaching in undergraduate initial teacher education programs in the School of Education.

Classroom discussions with pre-service teachers (PSTs) at tertiary level, lecturers and tutors can address some of the normative perceptions of masculinities and femininities attributed to job stereotypes by examining gendered discourses as and if they appear in the literature within prescribed coursework. In a second year Bachelor of Education course, PSTs debate how roles are portrayed in children's literature. They are then invited to participate in online forums to critically interrogate the literature and form opinions about how they will approach gendered conversations in primary classrooms. A critical literacy approach encourages young children to think critically about social issues and helps them to process the stream of information that enters their conscious and sub-conscious minds with greater sensitivity (Minott, 2011).

Although academics reported some trepidation concerning conducting classroom dialogues about gender, race and class with pre-service teachers (PSTs), all felt that these were important discussions to explore as they addressed some unexamined stereotyped perceptions. Academics who identified as white cis gender middle class women stated that they sometimes felt their identifications and background were an advantage in the sense that the majority of students could relate to them, but they felt that this situation made it difficult to discuss difference and diversity. However, another academic who identified as a working-class woman of colour commented that she also found gender, race and class extremely difficult to discuss in class as she was often either perceived as the embodiment of difference or her difference to hegemonic narratives of race, gender and class was 
completely ignored by students who seemed to adopt a kind of colour-blindness to deal with her wilfully diverse presence in their midst. Due to this academic's wilful insistence on the importance of analysing and breaking down conventional narratives of gender, race and participation in STEMM, she developed a curriculum design that incorporated cultural and political vignettes (CPVs) to explore a range of issues regarding gendered stereotypes and participation in STEMM. "CPVs are mock cultural and political situations that are presented to teachers so that they can practice the complex decision-making skills that they need to use in [...] diverse classrooms" (Darvin, 2011, p. 346).

While CPVs are similar to role plays, they incorporate space to permit reflection, analysis and discussion of experiences. In this way, CPVs move beyond the dimensions of role play by enabling participants to adopt a range of subject positions that may even be contradictory at times. By experiencing the CPV as a means of exploring a diversity of identities and backgrounds, PSTs are enabled to reflect on their own subject positions, cultural identifications and actions regarding a variety of social, political, and schoolbased concerns. In conjunction with these examinations of social, political and cultural characteristics, the experience of completing CPVs allows PSTs to reflect on their individual teaching approaches as well as encouraging them to design and implement learning activities for their own teaching practices. From these reflections planned and unplanned conversations occurred that troubled and often encouraged an undoing of gender.

Prior to the CPV's commencement, any issues or potential problems were noted and possible ways of dealing with these issues were recorded. At the end of the CPV, the PSTs examined their own experience in relation to their values and beliefs and entered into dialogue with their peers, sharing, where they were comfortable, what they had learned. Relevant formal literature on the topic was included through breaks in the process where everyone turned to what they felt were enlightening readings previously made available to PSTs. It is important to note that CPVs were employed after four weeks of tutorials in which values and assumptions were discussed as well as ways in which gender and other characteristics of diversity might moderate students' learning in general and specifically in the area of STEMM.

One of the CPV scenarios used with PSTs is as follows:

Simon, a graduate teacher is the designated IT expert in his school with a diverse student population. With a full workload, teaching technology and design in Years 7 and 8, Simon has a number of girls who are increasingly becoming disengaged while the boys in the classes often state they are bored by the course material taught.

Simon is searching for ways to stop students from disengaging from working with technologies.

Discuss, write and perform two short scenes that sum up the cultural and gender issues in this case. 
After this CPV was discussed in tutorials, PSTs investigated, discussed and performed role plays that were based on notions of conventional femininity, hegemonic masculinity and assumptions about cultural diversity. Discussions tended to focus on some stereotypical thinking regarding what might engage female and male students in STEMM and IT learning activities. Here, notions of hegemonic masculinity and discourses of meritocracy - if females are worthy and talented enough, they will be able to participate in STEMM and IT based activities - surfaced. Some strong and careful diversity work was needed from the tutor in this situation, to both listen to student comments and challenge normative thinking while also foregrounding student voices that brought up ideas beyond the conventional. From these comments, lists of strategies and local community resources that could be employed to assist teachers to move beyond stereotypical thinking and actions regarding gender were developed.

Feedback from the PSTs regarding CPV participation indicated that they found the CPVs to be helpful in exploring subject positions that were different to their own within a safe CoP. Despite generally positive student involvement with CPVs, there were some difficulties in their implementation. At times PSTs struggled with adopting and maintaining a persona that was different to their own, particularly when it needed to be maintained throughout the CPV in a range of situations. Some PSTs displayed some wariness regarding the CPV process when their thinking was challenged, especially those attitudes prevalent in their own local communities. A few students did not participate directly in performing or role playing in the CPV; instead, these students wrote responses. In these cases, written expression was perceived to be less confronting than direct physical involvement in the CPV. At times, the urge to 're-do' gender was strongly felt in the tutorial room and was combatted by the equally powerful urge reportedly felt by the tutor to wilfully challenge convention.

The experience of using CPVs to investigate gender issues regarding STEMM and IT useage in education activities emphasized the importance of bringing together theory and practice in supportive CoP environments when working with future teachers and educators. It also underlined the need for all teaching resources and language at all levels of education - early childhood, primary and secondary schools as well as tertiary institutions - to be inclusive of a diversity of student characteristics, backgrounds and contexts. These practices of inclusive teaching were especially important for PSTs and students who, while they are currently situated in rural/regional areas that lack diversity, after graduation, may teach in education environments with diverse populations.

\section{Wilful undoing of gender through policy and institutional culture}

As well as wilfully undoing gender through the design and development of interactive and challenging teaching activities, SEITWG members also continued their diversity work through CoP approaches. By using strategic dialogue with more senior staff members and working collaboratively and supportively, SEITWG members continued to undo gender at the levels of policy and also workplace culture. SEITWG members used formal 
opportunities in staff meetings as well as informal gatherings in the lunchroom to open up dialogue around general university policy that had gendered implications for staff. Maternity leave provisions and employment policy and practices were two of the main areas of concern. The former is still being debated with a considerable amount of work still to be accomplished in this domain. However, dialogue focusing on the latter issues has generated considerable change.

It is important to note that an integral aspect of SEITWG's strategic use of CoP approaches entailed wilful subjects finding allies across fault lines of gender and power with more senior male academics. In meetings and informal discussions with senior staff members, SEITWG individuals wilfully and consistently foregrounded the problems entailed in traditional approaches to academic employment that focus on the applicant's research output rather than considering both scholarship and teaching. This approach does not take into account, for example, gaps in work history due to family responsibilities which affects a significant percentage of female academics (Baker, 2010) and also the higher concentration of women teaching and completing 'academic housekeeping' tasks in the academy (Guarino, 2017). As a result of these discussions, a consensus was achieved where all job applicants would be considered on the basis of their achievements relative to opportunity as well as knowledge and understanding of contemporary pedagogies - thus, giving equal weight to research and teaching. This meant that the predominantly female candidates who had taken leave or assumed part-time work and carer responsibilities were assessed on evidence demonstrating their aptitude and willingness to undertake research and teach even if they did not strictly meet general academic guidelines for research outputs. One senior academic commented that if a candidate "could keep her research ticking over while on leave, that is evidence that she could build her research when she is back fulltime at work". From the adoption of this focus and process promoted by the coalition of wilful subjects, an increased number of female staff have been employed over the last eight years.

In addition to being instrumental in changes in understandings and implementation of employment procedures, carried along fault lines of power and gender, SEITWG members have also been wilfully driving forces behind workplace cultural change. For example, SEITWG members and their more senior allies have challenged gendered representations of women in videos produced for IT academic staff training and School promotion purposes. In one case, there was an obvious lack of female characters as well as a dependence on gender stereotypes in a series of videos of different scenarios involving IT academic and industry staff that was produced for SEIT. The coalition of the wilful identified and challenged this gaping lack of female presence, undoing normative narratives. When a senior academic attempted to re-do conventional gender constructions, stating "But this [the gender stereotypes depicted] is how it is", members of SEITWG, with an impassioned wilfulness, identified, described and analysed normative narratives of gender generally and specifically in the domain of IT. Then SEITWG members detailed how this re-doing of gender would impact negatively on workplace culture and relations within 
the School of IT with possible repercussions across Schools throughout the university and in communities outside the tertiary institution. Due to this wilful undoing of gender conventions, the videos were re-shot with more women characters in the scenarios in both technical and support roles.

\section{CONCLUSION}

In conclusion, SEITWG brings together a diverse range of women who act individually and collectively using Community of Practice (CoP) approaches with the purpose of wilfully undoing gender stereotypes and dominant discourse concerning STEMM and IT. These 'undoings' are interventions involving a coalition of wilful subjects - allies whose subject positions cross fault lines of gender and power. Undoings are wilfully worked into collaborative and collegial work across the university and in communities outside this tertiary institution. Moments of undoing gender are also integrated into pedagogy as well as curriculum design and development. SEITWG members employ discussions of language use and concrete examples of moving beyond traditional notions of gender infuse courses in education and IT. The wilful use of CPVs enables the undoing of gender in planned and unplanned conversations. In addition, wilful examinations of normative gendered narratives are strategically mobilized in formal and informal meetings and discussions to challenge policy and workplace culture.

In this framework of wilful undoings of conventional gender narratives, the acknowledgement of the lived experience of the individual recorded in written reflection, journaling, notes from meetings and conversations were used as the basis for scholarly interrogation in the form of a reflective self-study. As a result of the positive responses from those within and people outside SEITWG, the authors argue that the strategies and activities we have employed in order to wilfully undo conventional gender narratives are transferable to other women's groups both within Australia and also on a global stage. This framework provides ways to identify and undo dominant discourse regarding stereotypes concerned with gender and STEMM especially in areas of policy and workplace culture. The framework could also contribute towards the development of a high-quality inclusive education for pre-service teachers in universities throughout the world. With consideration of the work that SEITWG has done concerning collegial collaboration, curriculum, pedagogy, policy examination and workplace culture investigation, there is little doubt that the group has produced critically considered, effective and passionately wilful undoings of gender.

\section{REFERENCES}

Ahmed, S. (2010). The Promise of Happiness. North Carolina: Duke University Press.

Ahmed, S. (2012). On being included; Racism and Diversity in Institutional Life. Durham and London:

Duke University Press.

Ahmed, S. (2014). Wilful Subjects. Durham and London: Duke University Press.

Ahmed, S. (2017). Living a feminist life. Durham and London: Duke University Press. 
Baker, M. (2010). Choices or Constraints? Family Responsibilities, Gender and Academic Career. Journal of Comparative Family Studies, 41(1), 118.

Bass, L., Anderson-Patton, V. and Allender, J. (2002). Self-study as a way of teaching and learning: A research collaborative re-analysis of self-study teaching portfolios. In J. Loughran and T. Russell (Eds.), Improving Teacher Education Practices Through Self-Study (pp. 56-70). London: RoutledgeFalmer.

Biraimah, K. (1982). Different Knowledge for Different Folks: Knowledge Distribution in a Togolese Secondary School. In P. Altbach, R. Arnove and G. Kelly (Eds.), Comparative Education (pp. 161175). New York: Macmillan.

Carroll, P. J., Shepperd, J. A. and Arkin, R. M. (2009). Downward self-revision: Erasing possible selves. Social Cognition, 27, 550-578.

Chen, P., Lambert, A. and Guidry, K. (2010). Engaging online learners: The impact of Web-based learning technology on college student engagement. Computers \& Education, 54, 1222-1232.

Cheryan, S. and Plaut, V. C. (2010). Explaining underrepresentation: A theory of precluded interest. Sex Roles, 63, 475-488.

Cheryan, S., Plaut, V. C., Davies, P. and Steele, C. M. (2009). Ambient belonging: How stereotypical environments impact gender participation in computer science. Journal of Personality and Social Psychology, 97, 1045-1060.

Cho, H. and Schwarz, N. (2008). Of great art and untalented artists: Effort information and the flexible construction of judgmental heuristics. Journal of Consumer Psychology, 18, 205-211.

Clancy, K., et al. (2017). Double jeopardy in astronomy and planetary science: Women of color face greater risks of gendered and racial harassment. Journal of Geophysical Research: Planets, 122, $1610-1623$.

Cohen, L. (2014). Why Computer Science needs women. Retrieved from https://www.marieclaire.com/.

Cohen, L. and Duberly, J. (2017). Five unconscious biases that hold back female researchers. Retrieved from https://www.theguardian.com/higher-education-network/2017/mar/23/five-unconscious-biases-that-hold-back-women-researchers.

Colatrella, C. (2014). Why STEM Students Need Gender Studies. Retrieved from https://www.aaup.org/ article/why-stem-students-need-gender-studies\#.WzMSWqczaM8.

Connell, R. W. (1989). Cool Guys, Swots and Wimps: The Inter-play of Masculinity and Education. Oxford Review of Education, 153, 291-303.

Connell, R. W. (1996). Teaching the boys: New research on masculinity, and gender strategies for schools. Teachers College Record, 98(2), 206-235.

Correa, T., Hinsley, A. and Gil de Zuniga, H. (2010). Who interacts on the Web? The intersection of users' personality and social media use. Computers in Human Behavior, 26(2), 247-253.

Cross, S. E. and Madson, L. (1997). Models of the self: Self-construals and gender. Psychological Bulletin, 122, 5-37.

Crotty, M. (1998). The Foundations of Social Research: Meaning and Perspective in the Research Process. New York: Sage.

Cundill, G., Roux, D. J. and Parker, J. N. (2015). Nurturing communities of practice for transdisciplinary research. Ecology and Society, 20(2), 22.

Darvin, J. (2011). Situated performances in a graduate teacher education course: an inquiry into the impact of Cultural and Political Vignettes (CPVs). Teachers and Teaching: theory and practice, 17(3), 345-364.

Dasgupta, N. (2011). Ingroup experts and peers as social vaccines who inoculate the self-concept: The stereotype inoculation model. Psychological Inquiry, 22, 231-246. 
Dasgupta, N. and Stout, J. G. (2014). Girls and Women in Science, Technology, Engineering, and Mathematics: STEMing the Tide and Broadening Participation in STEM Careers. Policy Insights from the Behavioral and Brain Sciences, 1(1), 21-29.

Deutsch, F. (2007). Undoing Gender. Gender and Society, 211, 106-127.

Ehrlinger, J. and Dunning, D. (2003). How chronic self-views influence (and potentially mislead) estimates of performance. Journal of Personality and Social Psychology, 84, 5-17.

Flick, U. (2007). Designing Qualitative Research. New York: Sage.

Gilbert, R. and Gilbert, P. (1998). Strategies for Change. In R. Gilbert and P. Gilbert (Eds.), Masculinity Goes to School (pp. 222-251). London: Routledge.

Guarino, C. (2017). Why higher ed needs to get rid of the gender gap for 'academic housekeeping'. The Conversation. Retrieved from https://theconversation.com/why-higher-ed-needs-to-get-rid-of-thegender-gap-for-academic-housekeeping-82135.

Hamilton, M. and Pinnegar, S. (2009). Self-Study of Practice as a Genre of Qualitative Research: Theory, Methodology, and Practice. Netherlands: Springer.

Hannafin, M. and Land, S. (1997). The foundations and assumptions of technology-enhanced student-centered learning environments. Instructional Science, 25(3), 167-202.

Hill, C., Corbett, C. and St Rose, A. (2010). Why so few? Women in Science, Technology, Engineering, and Mathematics. Washington: American Association of University.

Jericho, G. (2017). No more nappy valley but childcare still an issue for working women. Retrieved from https://www.theguardian.com/australia-news/grogonomics/2017/dec/12/no-more-nappy-valley-butchildcare-still-an-issue-for-working-women.

Kezar, A. and Gehrke, S. (2017). Sustaining communities of practice focused on STEM reform. The Journal of Higher Education, 88(3), 323-349.

Lave, J. and Wenger, E. (1991). Situated Learning: legitimate peripheral participation. Cambridge: Cambridge University Press.

LaBoskey, V. (2004). The Methodology of Self-Study and Its Theoretical Underpinnings. In J. Loughran, L. Hamilton, V. LaBoskey and T. Russell (Eds.), International Handbook of Self-Study of Teaching and Teacher Education Practices (pp. 817-869). New York: Springer.

Lloyd, C., Mensch, B. and Clark, W. (2000). The Effects of Primary School Quality on School Dropout among Kenyan Girls and Boys. Comparative Education Review, 44(2), 113-147.

Mavriplis, C., Heller, R., Beil, C., Dam, K., Yasinskaya, N., Shaw, M. and Sorensen, C. (2010). Mind the gap: Women in STEM career breaks. Journal of Technology Management \& Innovation, 5(1), 140-151.

Milgram, D. (2011). How to recruit women and girls to the Science, Technology, Engineering, and Math (STEM) classroom. Technology and Engineering Teacher, 71(3), 4-11.

Minott, M. (2011). Reflective teaching, critical literacy and the teacher's tasks in the critical literacy classroom. A confirmatory investigation. Reflective Practice, 12(1), 73-85.

Myton, D. (2018). Fast forward to gender equity: New best practice guidelines for Australian universities. Retrieved from https://campusmorningmail.com.au/news/fast-forward-to-gender-equity/.

Nath, V. (2017). Change the way we run universities to unlock women's talent. Times Higher Education. Retrieved from https://www.timeshighereducation.com/unijobs/article/change-the-way-we-run-universities-to-unlock-women-s-talent/.

Pascoe, C. J. (2007). Dude, You're a Fag: Masculinity and Sexuality in High School. Berkeley: University of California Press.

Pinnegar, S. and Hamilton, M. (2009). Self-Study of Practice as a Genre of Qualitative Research: theory, methodology and practice. New York: Springer. 
Renold, E. (2006). Gendered Classroom Experiences. In C. Skelton, B. Francis and L. Smulyan (Eds.), The SAGE Handbook of Gender and Education (pp. 439-452). Thousand Oaks: Sage.

Russell, T. (2010). Improving the quality of teaching and learning: Lessons learned as a teacher educator. Retrieved from https://atea.edu.au/wp-content/uploads/2010_russell.pd.

Sadler, D. (2017). Women in STEM Booming. But still much work to be done. Information Age, ACS. Retrieved from https://ia.acs.org.au/article/2017/women-in-stem-booming.html.

Samaras, A. P. and Freese, A. R. (2009). Looking back and looking forward: An historical overview of the self-study school. In C. A. Lassonde, S. Galman and C. Kosnik (Eds.), Self-Study Research Methodologies for Teacher Educators (pp. 3-19). Rotterdam: Sense.

Spelke, E. S. (2005). Sex differences in intrinsic aptitude for mathematics and science? A critical review. American Psychologist, 60, 950-958.

Steele, C. M. (1997). A threat in the air: How stereotypes shape intellectual identity and performance. American Psychologist, 52, 613-629.

Steffens, M. C. and Jelenec, P. (2011). Separating Implicit Gender Stereotypes Regarding Math and Language: Implicit Ability Stereotypes are Self-serving for Boys and Men, but not for Girls and Women. Sex Roles, 64(5/6), 324-335.

Stout, J. G., Dasgupta, N., Hunsinger, M. and McManus, M. A. (2011). STEMing the tide: Using ingroup experts to inoculate women's self-concept in science, technology, engineering, and mathematics (STEM). Journal of Personality and Social Psychology, 100, 255-270.

Tavani, H. (2016). Ethics and technology: Controversies, questions, and strategies for ethical computing. Hoboken: Wiley.

Thoman, D. B., White, P. H., Yamawaki, N. and Koishi, H. (2008). Variations of gender-math stereotype content affect women's vulnerability to stereotype threat. Sex Roles, 58, 702-712.

Thorne, B. (1993). Gender Play: Girls and Boys in School. Buckingham: Open University Press.

Unterhalter, E. (1999). The Schooling of South African Girls. In C. Heward and S. Bunwaree (Eds.), Gender, Education and Development: Beyond Access to Empowerment (pp. 49-64). London: Zed Books.

Vogt, C., Hocevar, D. and Hagedorn, L. (2007). A social cognitive construct validation: Determining women's and men's success in Engineering programs. The Journal of Higher Education, 78(3), 337-364.

Wenger, E. (1999). Communities of practice. Learning, meaning, and identity. Cambridge: University Press.

West, C. and Zimmerman, D. (1987). Doing Gender. Gender and Society, 1, 125-151. 